\title{
IbM WIRAUSAHA CARPET LAUNDRY DALAM UPAYA PENINGKATAN TEKNOLOGI PROSES DAN MANAJEMEN OPERASIONAL BISNIS
}

\author{
Sufiyanto $^{1)}$, R Djoko Andrijono ${ }^{2)}$, Ni Made Wiati ${ }^{3)}$ \\ ${ }^{123)}$ Fakultas Teknik, Universitas Merdeka Malang \\ Email : sufiyanto@unmer.ac.id \\ Email : djoko.andrijono@unmer.ac.id \\ Email : nimade.wiati@unmer.ac.id
}

\begin{abstract}
Abstrak
Bisnis laundry carpet menjadi sebuah bentuk wirausaha yang potensi dikembangkan di daerah perkotaan. Peningkatan kualitas produk jasa dan produktivitas menjadi daya saing bagi wirausaha laundry carpet. Kendala proses pencucian dan pengeringan karpet menjadi hambatan bagi usaha laundry carpet di musim penghujan. Selain itu ongkos tenaga kerja dan ketersediaan ruang untuk pengeringan muncul bagi usaha laundry carpet di perkotaan. Tujuan program IbM ini adalah untuk menyelesaikan masalah operasional yang dihadapi oleh wirausaha laundry carpet agar dapat meningkatkan kualitas layanan jasa dan produktivitasnya. Metode yang diterapkan adalah perbaikan teknologi pencucian dan pengeringan karpet dengan mesin spinning carpet serta manajemen operasional dalam pengelolaan usaha laundry carpet. Hasil yang dicapai menunjukkan operasional secara teknis setelah menggunakan mesin spinning carpet 3 kali lebih cepat dan pengelolaan manajemen lebih baik. Workshop teknologi mesin spinning carpet, manajemen operasional dan bisnis kepada mitra wirausaha laundry carpet sangat berperan dalam mengembangkan usaha bisnis yang lebih baik.
\end{abstract}

Kata Kunci: Laundry Carpet, Teknologi Proses, Manajemen Operasional Bisnis

\begin{abstract}
Carpet laundry business able to become a potential entrepreneurship developed in urban areas. Improved quality and productivity of services product can be a competitiveness for carpet laundry business. Constraints on the process of washing and drying the carpet becomes a problem for the carpet laundry business in rainy season. In addition, constraints of labor and space availability for drying arises for carpet laundry business in urban areas. This IbM program aims to resolve the operational problems faced by the carpet laundry business in order to improve service quality and productivity. The applied methods are technology improvement of washing and drying carpet with carpet spinning machine as well as operational management in the carpet laundry business. The achieved results demonstrate the technical operations after using carpet spinning machine 3 times faster and management better than before. The workshops of carpet spinning machine technology, operational and business management to partners the carpet laundry business were very instrumental in developing the better business.
\end{abstract}

Keywords: Carpet Laundry, Process Technology, Business and Operations Management

\section{PENDAHULUAN}

\section{a. Analisis Situasi}

Penggunaan karpet telah lama dikenal oleh masyarakat secara luas sebagai alas duduk maupun aksesoris yang digunakan untuk memperindah penataan ruang atau rumah. Berbagai motif dan model karpet telah berkembang luas dengan berbagai macam ukuran maupun bahan yang digunakan. Di era modern penggunaan karpet merupakan kebutuhan masyarakat luas baik untuk keperluan keluarga/rumah maupun dekorasi di kantor, hotel maupun gedung bahkan tempat ibadah seperti masjid.

Dalam penggunaannya, karpet memerlukan pemeliharaan agar fungsi dan kegunaannya dapat dijaga dengan baik. Ada beberapa metode perawatan karpet misalnya dengan menggunakan penyedot debu (vacuum cleaner) untuk membersihkan kotoran debu atau mengggunakan metode dry cleaning untuk beberapa jenis karpet yang dipasang secara permanen di kantor maupun gedung. Penggunaan penyedot debu hanya dapat dilakukan untuk membersihkan debu kering yang menempel di karpet atau untuk perawatan ringan yang dapat dilakukan setiap hari. Dalam kondisi tertentu seperti adanya kotoran basah atau terkena tumpahan makanan dan minuman, maka karpet tidak dapat hanya dibersihkan dengan menggunakan penyedot debu tetapi harus dilakukan pencucian dan pengeringan.

Dalam hal perawatan karpet dengan melakukan pencucian, pemilik karpet menghadapi beberapa kendala/kesulitan misalnya keterbatasan waktu, ruang kerja dan tenaga. Sejalan dengan 
perkembangan jaman, muncul jasa pencucian yang dikenal dengan jasa laundry. Semula jasa laundry hanya untuk kebutuhan mencuci pakaian, tetapi kemudian berkembang sampai dengan munculnya laundry karpet. Salah satu wirausaha laundry yang juga menyediakan jasa pencucian karpet adalah Bali Laundry yang berada di Perumahan Joyo Grand Blok I-1 No. 6 Kelurahan Merjosari Kecamatan Lowokwaru Kota Malang. Wirausaha Bali Laundry merupakan wirausaha rumahan yang dirintis oleh bapak Nengah Asung Dana yang didirikan sejak tahun 2009 dengan 3 orang tenaga kerja untuk menjalankan usaha jasa laundry.

Potensi usaha yang dimiliki oleh Bali Laundry sangat menjanjikan karena keberadaan tempat usaha ini berada di lingkungan perumahan dan sekitarnya juga merupakan kawasan perumahan. Di samping hal tersebut, mengingat potensi pertumbuhan perumahan baru di kota Malang yang cukup besar, maka wirausaha laundry ini merupakan wirausaha yang sangat menjanjikan. Hal ini disebabkan oleh kondisi masyarakat modern di perkotaan cenderung sibuk tidak memiliki waktu dan tenaga yang cukup untuk melakukan pekerjaan rumah tangga seperti mencuci pakaian atau karpet. Di samping itu masyarakat kota tidak memiliki tempat yang memadai untuk mencuci dan menjemur, sehingga bisnis laundry menjadi demikian berkembang.

Faktor lain yang juga berperan dalam menunjang berkembangnya bisnis laundry di kota Malang adalah banyaknya masyarakat urban (pendatang) yang sebagian besar sebagai mahasiswa karena Malang merupakan kota pendidikan dengan jumlah mahasiswa pendatang yang sangat besar. Ditinjau dari segi kemampuan ekonomi, biasanya mereka berlatar belakang ekonomi menengah atas, sehingga mereka cenderung menggunakan jasa laundry untuk mencuci pakaian, selimut maupun karpet. Berdasarkan kondisi geografis kota Malang berada di dataran tinggi dengan curah hujan tinggi menjadi alasan bagi masyarakat urban untuk memilih menggunakan jasa laundry.

Pengelolaan wirausaha di Bali Laundry Carpet ini masih menggunakan manajemen kekeluargaan. Penanganan masalah keuangan, pelayanan dalam pesanan, dan pemasaran masih ditangani sendiri oleh bapak Nengah Asung Dana dan keluarga. Sistem keuangan sudah dilakukan pemisahan antara modal usaha dengan keuangan untuk keperluan rumah tangga. Dalam pemasaran dilakukan dengan cara menggunakan media brosur maupun media koran.
Untuk media brosur sendiri difokuskan ke rumahrumah kos maupun kontrakan mahasiswa atau mahasiswi yang terlalu fokus dengan kuliah, sehingga tidak memiliki waktu untuk mengurus kebersihan karpet. Pada kondisi tersebut peluang untuk memperoleh order atau pesanan dapat diperoleh.

Ditinjau dari sumber daya manusia tenaga kerja yang terlibat di Bali Laundry, rata-rata tenaga kerja berlatar belakang pendidikan lulusan SMU. Semua tenaga kerja yang terlibat adalah perempuan dan usia rata-rata di bawah 30 tahun. Ditinjau dari faktor usia, mereka masih sangat produktif, sehingga memungkinkan untuk pengembangan usaha yang lebih maju. Tenaga kerja tersebut, berasal dari masyarakat disekitarnya dan ini merupakan peluang usaha yang berpotensi dapat menciptakan lapangan pekerjaan untuk mengatasi dampak pengangguran.

Ditinjau dari sisi potensi usaha jasa laundry sangat menjanjikan dengan kondisi masyarakat konsumen di daerah perkotaan seperti Malang. Tetapi bukan berarti tidak ada hambatan dalam pengelolaan bisnis laundry tersebut. Dengan adanya kondisi curah hujan yang tinggi dan keterbatasan lahan yang digunakan untuk mencuci dan menjemur timbul kesulitan dalam proses pencucian dan pengeringan karpet. Proses pencucian dan pengeringan karpet membutuhkan penanganan yang berbeda, karena karpet memiliki karakteristik ketebalan dan kekakuan yang tidak bisa dicuci dan dikeringkan seperti halnya kain atau pakaian. Selain itu tentunya juga membutuhkan tenaga dan teknis yang lebih berat dibanding dengan kain atau pakaian.

Seiring dengan perkembangan waktu, persaingan bisnis jasa laundry semakin meningkat karena semakin banyaknya wirausaha yang membuka jasa laundry. Dengan kondisi tersebut, maka diperlukan manajemen pengelolaan bisnis jasa laundry tersebut. Manajemen pengelolaan yang dimaksud dapat berupa manajemen bisnis dan manajemen operasional. Hal ini sangat diperlukan untuk menunjang pengelolaan bisnis jasa laundry agar memiliki daya saing yang tinggi dan mampu mengembangkan usaha secara lebih profesional dengan modal usaha yang lebih besar.

\section{b. Permasalahan Mitra}

Berdasarkan analisis situasi yang telah diuraikan di atas, terdapat beberapa permasalahan yang diperoleh berdasarkan hasil wawancara dan 
survey yang telah dilakukan dengan mitra usaha jasa Bali Laundry yaitu :

\section{1) Masalah teknis.}

Permasalahan teknis yang dialami oleh mitra usaha jasa laundry karpet adalah kendala teknis pencucian dan pengeringan karpet. Hal ini diakibatkan oleh karakteristik karpet dengan ketebalan dan kekakuan yang tidak dapat dicuci dan dikeringkan dengan cara biasa. Keterbatasan tenaga kerja atau teknik mencuci dan mengeringkan karpet memerlukan tenaga yang lebih besar, sehingga menyulitkan tenaga kerja dan membutuhkan waktu yang lebih lama jika dilakukan dengan cara manual. Faktor hambatan lainnya adalah keterbatasan tempat untuk mencuci dengan cara manual di mana karpet yang dicuci harus dibentangkan atau digelar, sehingga membutuhkan ruang atau tempat yang cukup luas.

Di samping hal tersebut di atas proses pengeringan dengan cara manual dilakukan dengan cara menggantungkan dan membentangkan karpet basah yang telah dicuci pada batang bambu atau pipa besi. Proses ini memerlukan waktu yang relatif lebih lama karena karpet tidak dapat diperas seperti halnya kain biasa dan menggantungkan proses alamiah air keluar dari lapisan karpet dengan gaya gravitasinya sendiri. Selanjutnya dikeringkan di udara terbuka yang terkena sinar matahari langsung. Proses penjemuran harus memperoleh panas maksimal karena apabila panas matahari kurang maksimal biasanya timbul bau tidak sedap.

Dalam proses pengeringan secara manual sering mengalami hambatan karena intensitas panas matahari di kota Malang relatif lebih rendah karena letak geografisnya sebagai daerah pegunungan dengan intensitas curah hujan yang tinggi. Sehingga kendala terbesar sering dialami oleh jasa pencucian karpet di musim hujan dengan lama musim hujan yang lebih lama dibanding musim kemarau.

\section{2) Masalah manajemen pengelolaan bisnis.}

Beberapa permasalahan yang terkait dengan manajemen pengelolaan yang dihadapi mitra antara lain :

a) Dari segi manajemen bisnis perlu diupayakan peningkatan usaha untuk pengembangan daya saing yang tinggi dan lebih profesional dalam menjalankan usaha bisnis jasa laundry. Manajemen bisnis ini dikaitkan dengan pengelolaan keuangan dan modal usaha untuk meningkatkan omset penjualan atau keuntungan usaha yang dijalankan dari bisnis jasa laundry tersebut. Pengelolaan modal usaha dan keuangan perlu dilakukan secara tepat agar dapat menjalankan usaha dengan baik, memperoleh modal usaha dan melakukan investasi secara tepat. Dengan manajemen bisnis yang baik diharapkan bisnis usaha dapat dikembangkan lebih luas, lebih besar bahkan mampu mengelola beberapa outlet jasa laundry dengan omset yang lebih besar.

b) Segi manajemen operasional perlu ditingkatkan untuk mengatur tenaga kerja, efektivitas kerja, sehingga diperoleh efisiensi usaha yang besar untuk meningkatkan keuntungan usaha. Selain itu manajemen operasional juga perlu dilakukan dengan baik agar kualitas produk dan ketepatan pengerjaan dapat tercapai untuk meminimalisir kesalahan dan cacat proses. Hal ini penting bagi sebuah usaha yang bergerak dibidang jasa seperti jasa laundry karpet. Pengaturan jumlah tenaga kerja yang tepat perlu dilakukan untuk menunjang pengembangan usaha yang lebih besar dan pengelolaan beberapa outlet dengan omset yang lebih besar.

Kegiatan ini diharapkan menghasilkan target dan luaran sebagai berikut :

a) Perbaikan teknologi proses pembilasan dan pengeringan karpet yang dapat meningkatkan kualitas layanan bagi wirausaha jasa laundry karpet.

b) Tercapai efisiensi dan efektifitas proses pencucian dan pengeringan karpet untuk menekan ongkos tenaga kerja, sehingga dapat meningkatkan pendapatan bagi pemilik usaha.

c) Dapat meningkatkan daya saing usaha mitra wirausaha jasa laundry dengan jasa laundry yang lain serta mengembangkan wirausaha jasa laundry berskala menengah.

Manfaat dari segi ekonomis yang dapat dicapai dalam pelaksanaan program $\mathrm{I}_{\mathrm{b}} \mathrm{M}$ ini adalah:

a) Adanya peningkatan pendapatan melalui disversifikasi jenis pekerjaan yang dapat ditangani setelah menggunakan mesin spinning carpet yang dimiliki oleh wirausaha jasa laundry. Dengan demikian dapat diperoleh pendapatan yang lebih besar dari kegiatan usaha yang dilakukan oleh mitra pada saat ini.

b) Perbaikan proses pencucian dan pengeringan karpet dengan berkurangnya waktu yang dibutuhkan seiring dengan meningkatnya kemampuan teknologi proses yang digunakan. 
c) Peningkatan daya saing wirausaha jasa laundry dan mampu mengembangkan usaha secara lebih profesional dengan modal usaha yang lebih besar.

Manfaat dari segi iptek adalah perbaikan teknologi dalam proses pencucian dan pengeringan karpet dapat meningkatkan kualitas dan efisiensi proses bagi wirausaha laundry karpet. Di samping hal tersebut, juga memberikan peluang untuk pengembangan teknologi pembuatan spinning machine carpet yang dapat digunakan untuk wirausaha laundry lainnya atau wirausaha sejenis yang menggunakan mesin spinning carpet. Adapun tujuan yang ingin dicapai dari kegiatan ini adalah sebagai berikut :

a) Meningkatkan pengembangan usaha Laundry Carpet dalam mengerjakan pesanan untuk pengeringan karpet.

b) Mengurangi waktu yang cukup lama saat proses pencucian dan pengeringan karpet berlangsung.

c) Mengurangi bau tidak sedap pada karpet yang terlalu lama dijemur karena proses pengeringan yang lama, dapat menimbulkan bau tak sedap.

\section{METODE KEGIATAN}

Dengan berlatar belakang masalah yang telah diuraikan diatas, maka solusi permasalahan yang ditawarkan oleh tim pelaksana program $\mathrm{I}_{\mathrm{b}} \mathrm{M}$ adalah sebagai berikut :

a) Peningkatan teknologi proses pencucian dan pengeringan karpet. Dengan dilakukannya peningkatan teknologi dalam proses pencucian dan pengeringan karpet dengan menggunakan mesin spinning carpet, maka efisiensi dan efektifitas proses dapat ditingkatkan. Peningkatan produktivitas akan mampu menekan biaya produksi dan tenaga kerja.

b) Peningkatan manajemen pengelolaan bisnis melalui pelatihan manajemen bisnis dan manajemen operasional. Dengan manajemen bisnis dapat diupayakan peningkatan usaha untuk pengembangan daya saing yang tinggi dan lebih profesional dalam menjalankan usaha bisnis jasa laundry. Sedangkan manajemen operasional dilakukan dengan dengan tujuan agar kualitas produk dan ketepatan pengerjaan dapat tercapai untuk mengurangi kesalahan dan cacat proses. Hal ini penting bagi sebuah usaha yang bergerak di bidang jasa seperti jasa laundry karpet. Pengaturan jumlah tenaga kerja yang tepat perlu dilakukan untuk menunjang pengembangan usaha yang lebih besar dan pengelolaan beberapa outlet dengan omset yang lebih besar.

Adapun langkah-langkah kegiatan yang akan dilakukan untuk mewujudkan 2 solusi masalah yang telah ditawarkan di atas adalah sebagai berikut :

1) Solusi pertama : Peningkatan teknologi proses pencucian dan pengeringan karpet.

Beberapa tahapan yang ditempuh seperti terlihat pada diagram alir berikut (gambar 1).

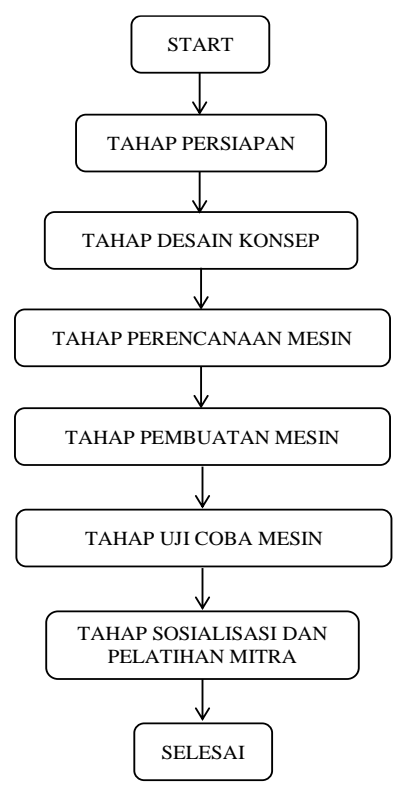

Gambar 1. Tahapan Pelaksanaan Program

Adapun kegiatan yang dilakukan pada setiap tahapan pelaksanaan program diuraikan sebagai berikut :

\section{- Tahap persiapan}

Dalam tahap ini dilakukan suvei lapangan ke mitra untuk mendapatkan gambaran tentang proses pencucian dan pengeringan karpet secara manual serta kendala lain yang terkait dengan proses tersebut. Selain itu juga untuk mendapatkan datadata teknis yang dibutuhkan dalam perencanaan mesin. Di samping itu juga dilakukan diskusi tentang hal-hal yang dibutuhkan dalam proses pencucian dan pengeringan karpet sebagai dasar awal untuk membuat konsep desain mesin spinning carpet yang akan direncanakan. Informasi tersebut antara lain : ketersediaan listrik yang mencukupi dengan adanya rencana pemakaian mesin spinning carpet, kesiapan tenaga operator yang akan menjalankan mesin spinning carpet, ketersediaan tempat dan rencana tata letak di dalam tempat usaha dengan adanya penambahan alat baru. 
- Tahap desain konsep

Pada tahap ini, tim pelaksana program $\mathrm{I}_{\mathrm{b}} \mathrm{M}$ mendiskusikan konsep desain mesin spinning carpet yang akan direncanakan berdasarkan informasi teknis dan kebutuhan yang diperoleh dari hasil diskusi dengan mitra pada tahap persiapan sebelumnya. Konsep desain yang diharapkan adalah sebuah lay out mesin spinning carpet yang dapat dioperasikan dengan mudah, metode perawatannya tidak rumit dan bentuk desain yang sederhana.

Sesuai hasil diskusi didapatkan suatu lay out bentuk desain mesin spinning carpet seperti yang ditunjukkan pada gambar 2. Selanjutnya lay out desain ini perlu didiskusikan dengan mitra usaha untuk mendapatkan masukan dari sisi operasional apakah sekiranya nanti ada perbaikan dari konsep desain tersebut. Apabila terdapat masukan dari mitra maka tim akan melakukan perubahan atau perbaikan pada konsep awal. Setelah konsep desain disetujui maka, dilanjutkan dengan tahap perencanaan alat.

\section{- Tahap perencanaan alat}

Dalam perencanaan alat diperlukan analisa awal terhadap komponen-komponen dari alat tersebut apakah komponen itu dibuat atau dibeli dan menentukan kesesuaian antara komponen yang dibeli dan yang dibuat agar tidak terjadi kesalahan dalam proses pemasangan atau perakitan.

Perencanaan dilakukan untuk menentukan dimensi dan bahan komponen yang akan digunakan pada alat tersebut. Bagian atau komponen yang direncanakan pada mesin spinning carpet meliputi :

1. perencanaan daya motor penggerak yang dipakai.

2. perencanaan tabung luar dan tabung dalam mesin spinning carpet.

3. perencanaan sistem transmisi sabuk $\mathrm{V}$ yang digunakan.

- Tahap pembuatan alat

Berdasarkan hasil perencanaan komponen dan detail setiap komponen, maka dilanjutkan dengan pembuatan mesin spinning carpet. Pengerjaan mesin ini dilakukan di bengkel dengan acuan gambar desain dan detail komponen yang sudah diperoleh pada tahap perencanaan. Selama proses pengerjaan tim pelaksana program $\mathrm{I}_{\mathrm{b}} \mathrm{M}$ akan melakukan pendampingan untuk memantau proses pembuatan alat.

\section{- Tahap uji coba}

Setelah mesin spinning carpet selesai, perlu dilakukan uji coba untuk mengetahui unjuk kerja dari mesin. Selain itu juga untuk mengetahui apakah mesin spinning carpet sudah beroperasi sesuai dengan yang direncanakan, atau diperlukan modifikasi sebelum diserahkan ke mitra usaha.

\section{- Tahap sosialisasi dan pelatihan mitra}

Pada tahap ini dilakukan sosialisasi penggunaan mesin spinning carpet serta sekaligus pelatihan untuk pengoperasian mesin spinning carpet tersebut. Dalam pelatihan juga diberikan metode perawatan dan pemeliharaan serta perbaikan ataupun penggantian komponen apabila terjadi kerusakan.

\section{Instrumen Pelaksanaan}

Indikator keberhasilan yang dicapai pada pelaksanaan program $\mathrm{I}_{\mathrm{b}} \mathrm{M}$ ini adalah berdasarkan kinerja atau performance yang dihasilkan pada proses pembilas dan pengeringan dengan mesin spinning carpet. Adapun beberapa hal yang dapat dipakai sebagai indikator kinerja mesin spinning carpet ini adalah :

- Jumlah tahapan proses pencucian yang dibutuhkan

- Waktu operasional

- Kemudahan dalam proses pengoperasian alat

- Tingkat ketersediaan komponen dan perawatan yang mudah

2) Solusi kedua : Peningkatan manajemen pengelolaan bisnis

Kegiatan yang akan dilakukan adalah memberikan pelatihan manajemen pengelolaan bisnis. Adapun materi pelatihan yang akan diberikan adalah manajemen operasional dan bisnis.

Dalam setiap pelaksanaan program di atas, mitra selalu dilibatkan secara aktif agar hasil yang dicapai pada pelaksanaan program ini dapat berhasil dengan baik dan maksimal. Sebagai contoh pada pelaksanaan program ke-1, mitra dilibatkan dalam proses diskusi pada tahap persiapan dan desain konsep. Setelah itu juga terlibat pada tahap uji coba, sosialisasi dan pelatihan penggunaan alat. Dalam pelaksanaan program ke-2, mitra aktif sebagai peserta dalam kegiatan pelatihan yang diberikan oleh tim pelaksana program $\mathrm{I}_{\mathrm{b}} \mathrm{M}$. Di samping hal tersebut, mitra usaha juga diharuskan untuk dapat mengajak 2 pemilik/wirausaha laundry yang lain dari daerah sekitar (selain mitra) untuk ikut serta dalam kegiatan pelatihan dan workshop.

Indikator untuk mengevaluasi pelaksanaan program kedua manajemen pengelolaan bisnis dapat ditentukan berdasarkan :

- Peningkatan pendapatan dari usaha yang dilakukan

- Perbaikan manajemen pengelolaan keuangan 
- Perbaikan tingkat pelayanan konsumen karena operasional berjalan dengan baik dan lancar.

- Tingkat kepuasan konsumen meningkat dengan berkurangnya keterlambatan dan hasil pengerjaan pencucian yang maksimal.
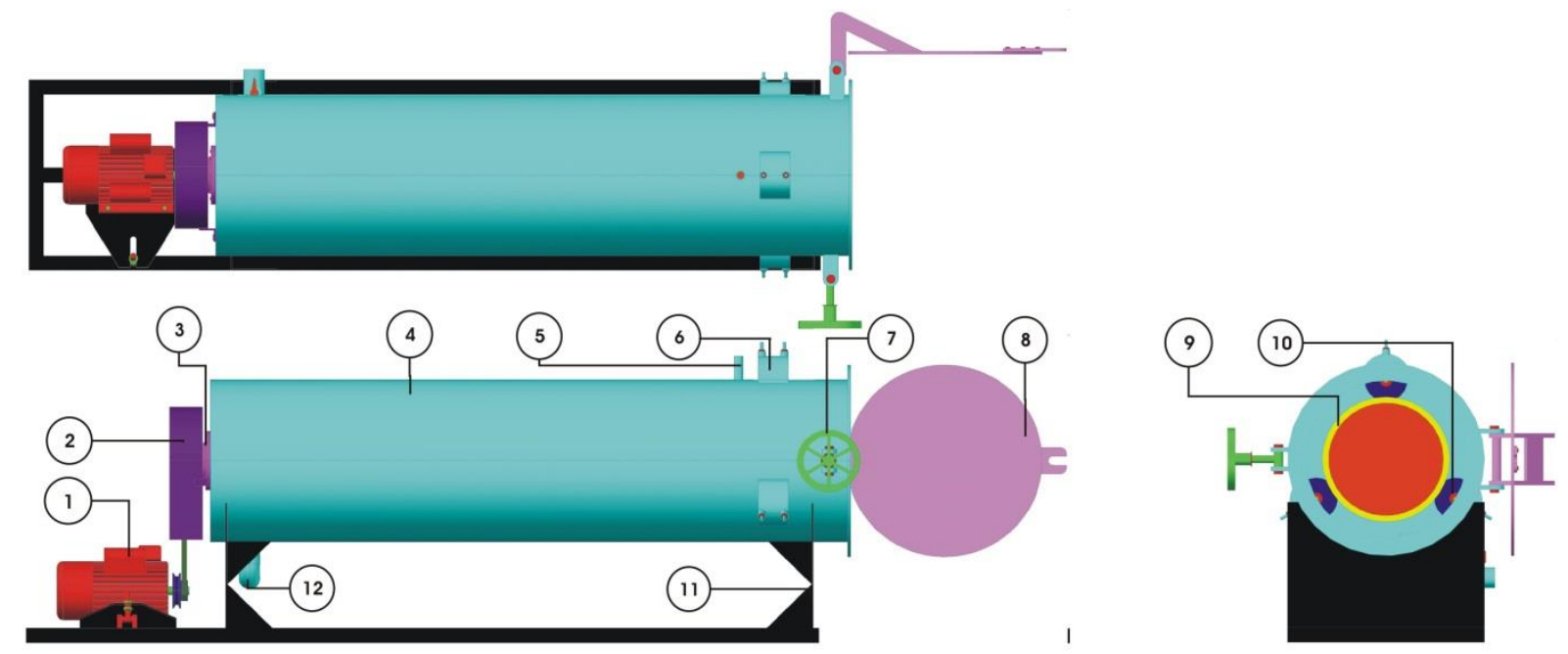

\begin{tabular}{ll}
\hline Keterangan : & \\
\hline 1. Motor Listrik & 4. Tabung Luar \\
2. Transmisi Sabuk V & 5. Saluran Air Masuk \\
3. Poros Penggerak & 6. Tutup Roller \\
\hline
\end{tabular}

Gambar 2. Desain Mesin Spinning Carpet

\section{HASIL DAN PEMBAHASAN}

\section{a. Proses Pembuatan Mesin Spinning Carpet}

Setelah melalui tahap desain, maka dilakukan proses pembuatan mesin spinning carpet. Proses pembuatan mesin ini dilakukan di bengkel teknik yang telah bekerja sama dengan tim pelaksana program IbM. Proses pembuatan mesin ini memerlukan waktu \pm 2 minggu. Adapun hasil akhir proses pembuatan mesin spinning carpet dapat dilihat pada gambar 3 .

Adapun spesifikasi dari mesin spinning carpet ini adalah :

- Motor penggerak : 1,5 KW/ 2 HP, 220 Volt, single phase induction motor, $1400 \mathrm{rpm}$.

- Jenis transmisi : belt transmssion, dengan dua rasio kecepatan $\dot{i}_{1}=3,4$ dan $i_{2}=4,3$.

- Type tabung pengering : tabung atau silinder, poros horizontal.

- Kontrol arah putaran tabung spinning : clock wise dan counter clockwise.

\section{b. Prinsip Kerja Mesin Spinning Carpet}

Penggunaan mesin spinning carpet adalah untuk proses pembilasan dan pengeringan karpet yang sudah dicuci. Proses pencucian karet masih dilakukan secara manual dengan menyabun dan menyikat karpet. Setelah itu untuk proses pembilasan dapat dilakukan dengan menggunakan mesin spinning carpet.

Cara pengoperasian mesin spinning carpet adalah sebagai berikut :

- Buka tutup tabung mesin dengan memutar pengunci tabung.

- Sebelum karpet dimasukkan ke dalam mesin spinning carpet, karpet harus digulung rapi memanjang dengan diameter lebih kecil dari diameter tabung dalam.

Masukkan gulungan karpet di mana arah gulungan karpet berlawanan dengan arah putaran mesin. Hal ini bertujuan saat mesin berputar, maka gulungan karpet dapat mengembang jika arah gulungan berlawanan dengan putaran tabung.

- Pastikan kran saluran pembuangan dalam posisi tertutup dan pintu penutup tabung terkunci rapat. Lalu masukkan air bilasan dari kran menggunakan selang melalui saluran air masuk yang terdapat di posisi atas tabung. Isikan air bilasan kira-kira 1/3 bagian tabung. 
- Proses pembilasan dapat dilakukan dengan menyalakan motor penggerak mesin spinning carpet. Gunakan waktu pembilasan kira-kira 10 menit untuk setiap kali proses pembilasan.

- Setelah 10 menit matikan sakelar motor penggerak dan buka kran pembuangan sampai seluruh air dalam tabung habis.

- Proses pembilasan dapat diulang 3-4 kali sesuai kebutuhan.

- Setelah proses pembilasan dilakukan proses pengeringan dengan cara spinning yaitu tabung berputar untuk membuang air yang berada di lapisan karpet tanpa menambahkan air ke dalam tabung. Proses spinning dapat dilakukan dengan waktu 10-15 menit sampai air dalam lapisan karpet keluar.

- Selanjutnya mengeluarkan karpet dari dalam tabung dan siap untuk dijemur guna proses pengeringan dengan sinar matahari.

Dengan penggunaan mesin spinning carpet ini lama proses pengeringan karpet menjadi lebih cepat 3 kali dibanding dengan cara sebelumnya. Hal ini disebabkan air yang terikat pada lapisan karpet basah dapat dikeluarkan sehingga mempercepat proses pengeringan dengan sinar matahari. Selain itu proses pembilasan menjadi lebih mudah dan kotoran yang masih menempel di karpet dapat terpisahkan karena pengaruh proses spinning. Ditinjau dari sisi proses pembilasan akan lebih memudahkan dan lebih cepat dibanding dengan cara sebelumnya.
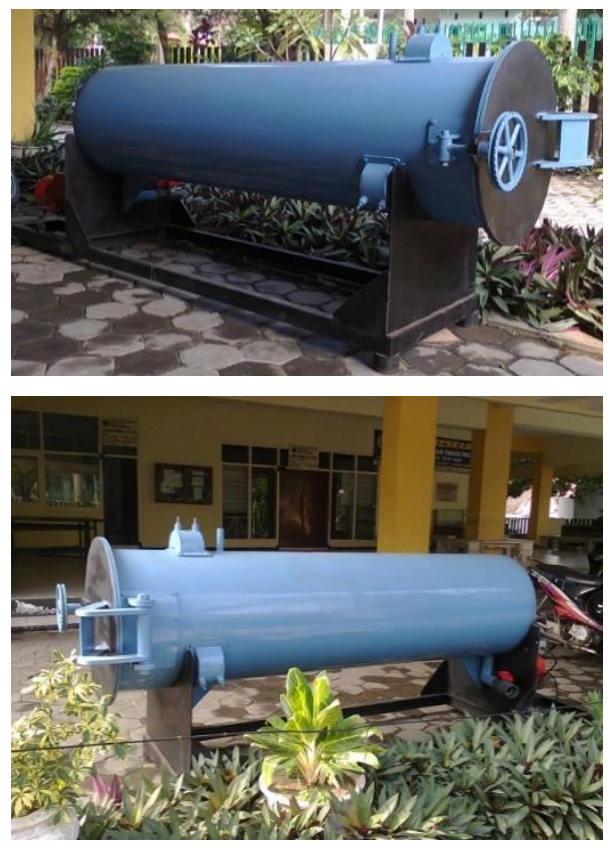

Gambar 3. Mesin Spinning Carpet

\section{c. Analisa Proses Pembuatan Komponen Mesin Spinning Carpet.}

Komponen-komponen utama mesin spinning carpet dapat dilihat pada layout desain gambar 2 . Analisa proses diperlukan untuk memberikan penjelasan tentang langkah-langkah proses pengerjaan yang dilakukan dalam pembuatan mesin spinning carpet.

Sebelum melakukan analisa proses diawali dengan analisa komponen untuk menentukan komponen yang dibuat dengan pengerjaan atau membeli. Adapun hasil analisa komponen utama terlihat pada table 1 di bawah. Komponen beli adalah komponen yang disediakan dengan membeli komponen tersebut yang ada di toko peralatan teknik. Sedangkan komponen buat adalah komponen yang dibuat atau dikerjakan oleh bengkel teknik dengan beberapa proses pengerjaan dan proses pemesinan (Afandi, R. R. A., dkk., 2011).

Berdasarkan analisa komponen, beberapa komponen dengan status buat dilanjutkan dengan analisa proses pembuatan komponen tersebut, (gambar 5). Analisa proses pembuatan yang akan diuraikan lebih detail dalam tulisan ini adalah proses pembuatan tabung luar dan tabung spinning.

Mekanisme proses pembuatan tabung dapat dijelaskan dengan proses pembentukan lembaran plat menjadi bentuk tabung atau silinder melalui proses roll bending (gambar 4). Proses ini merupakan proses pembentukan logam yang termasuk kategori pengerjaan dingin (cold working). Metode proses roll bending adalah proses pelengkungan plat dengan gaya bending yang diberikan oleh roll atas sebagai penekan dan mengatur radius kelengkungan (Sufiyanto, S., 2011). Sedangkan roll bawah kiri dan kanan berfungsi sebagai penahan tumpuan dan juga sebagai pengerak plat ke kiri dan ke kanan. Jumlah tahapan ditentukan oleh radius kelengkungan dan ketebalan plat yang dibentuk.

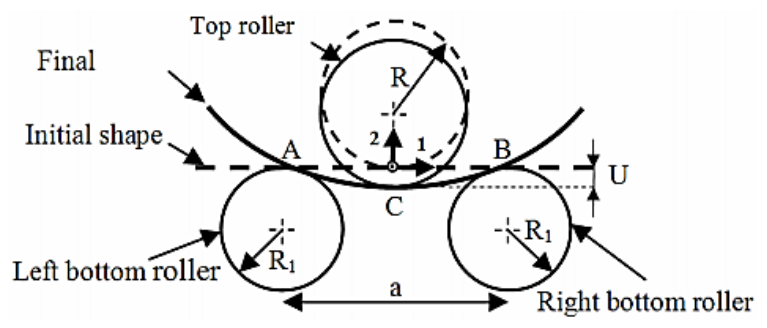

Gambar 4. Mekanisme Proses Roll Bending (Ktari, 2012) 
Tabel 1. Analisa Komponen Mesin Spinning Carpet

\begin{tabular}{|c|c|c|c|}
\hline Komponen Utama & Jumlah & Spesifikasi Material dan Dimensi & $\begin{array}{l}\text { Keterangan : } \\
\text { Beli/Buat }\end{array}$ \\
\hline 1. Motor Listrik & 1 & $2 \mathrm{HP}, 1400 \mathrm{rpm}$, motor induksi, single phase & Beli \\
\hline 2. Transmisi Sabuk V & 1 & V belt transmition & Beli \\
\hline 3. Poros Penggerak & 1 & $\begin{array}{c}\text { Flange shaft, } \varnothing_{\text {shaft }}=45 \mathrm{~mm}, \emptyset_{\text {flange }}=200 \mathrm{~mm}, \\
\emptyset_{\text {baut }}=12 \mathrm{~mm} \text { (6 lubang baut), Bahan ST } 37\end{array}$ & Buat \\
\hline 4. Tabung Luar & 1 & $\begin{array}{c}\text { Panjang }=2150 \mathrm{~mm}, \varnothing_{\text {out }}=550 \mathrm{~mm} \\
\emptyset_{\text {in }}=530 \mathrm{~mm}, \text { Bahan ST } 37\end{array}$ & Buat \\
\hline 5. Saluran Air Masuk & 1 & $\emptyset_{\text {out }}=28 \mathrm{~mm}, \varnothing_{\text {in }}=25 \mathrm{~mm}$, Bahan ST 37 & Buat \\
\hline 6. Tutup Roller & 3 & Lebar $=100 \mathrm{~mm}, \varnothing_{\text {out }}=160 \mathrm{~mm}, \mathrm{t}_{\text {plat }}=5 \mathrm{~mm}$, Bahan ST 37 & Buat \\
\hline 7. Pengunci Tabung Luar & 1 & $\varnothing_{\text {out }}=210 \mathrm{~mm}, \varnothing_{\text {in }}=170 \mathrm{~mm}, 6$ rim, Bahan ST 37 & Beli \\
\hline 8. Tutup Tabung Luar & 1 & $\varnothing=650 \mathrm{~mm}, \mathrm{t}_{\text {plat }}=10 \mathrm{~mm}$, Bahan ST 37 & Buat \\
\hline 9. Tabung Spinning & 1 & $\begin{array}{c}\text { Stainless Steel, Panjang }=1955 \mathrm{~mm}, \\
\emptyset=380 \mathrm{~mm}, \mathrm{t}_{\mathrm{plat}}=2 \mathrm{~mm}, \text { Stainless } \text { Steel }\end{array}$ & Buat \\
\hline 10. Roller & 3 & Lebar : $35 \mathrm{~mm}, \varnothing=140 \mathrm{~mm}, \varnothing_{\text {shaft }}=40 \mathrm{~mm}$ & Buat \\
\hline 11. Kerangka Mesin & 1 & $\begin{array}{c}\text { Bahan ST 37, Panjang }=2650 \mathrm{~mm} \text {, Lebar }=650 \mathrm{~mm} \text {, } \\
\text { Tinggi }=473 \mathrm{~mm} \text {, Profil Kotak }=60 \mathrm{~mm} \times 50 \mathrm{~mm} \text {, } \\
t_{\text {plat profil }}=1,5 \mathrm{~mm}\end{array}$ & Buat \\
\hline 12. Saluran Pembuangan & 1 & $\emptyset_{\text {katup buang }}=1,5$ inch, Bahan ST 37 & Buat \\
\hline
\end{tabular}

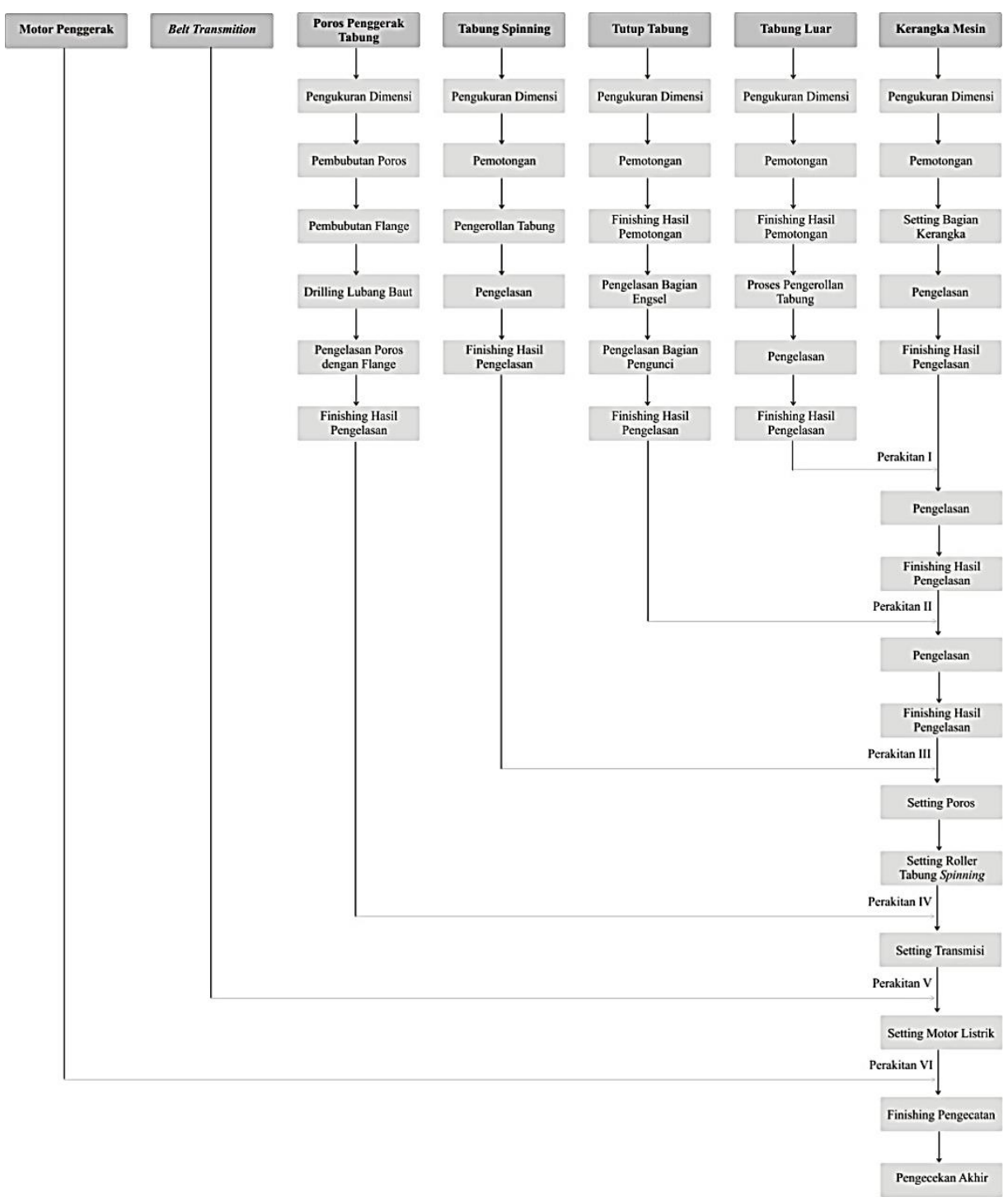

Gambar 5. Analisa Proses Pembuatan Komponen Mesin Spinning Carpet 

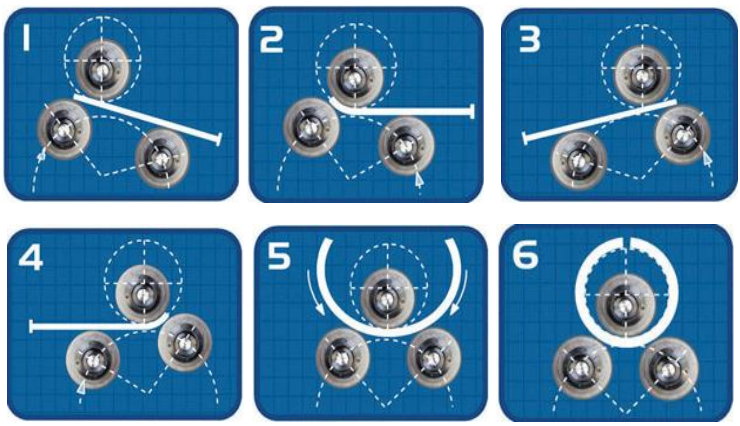

Gambar 6. Tahapan Proses Roll Bending (www.thefabricator.com)

Tahapan proses roll bending plat menjadi bentuk tabung berdasarkan gambar 6 dapat dijelaskan sebagai berikut :

a. Memposisikan salah satu ujung plat untuk ditekuk dengan radius awal yang sudah ditentukan.

b. Posisi roll atas dan roll sebelah kiri berfungsi sebagai penjepit, sedangkan roll sebelah kanan bergerak ke atas untuk menekuk ujung plat dengan radius awal.

c. Ujung plat yang lain juga ditekuk dengan radius awal yang sama dengan proses sebelumnya.

d. Posisi roll atas dan roll sebelah kanan berfungsi sebagai penjepit sedangkan roll kiri berganti bergerak ke atas untuk menekuk ujung plat dengan radius awal.

e. Roll bawah kiri dan kanan berputar sebagai penggerak mendorong plat bergerak ke kiri dan ke kanan secara berulang-ulang. Roll atas berfungsi untuk menekan plat membentuk kelengkungan yang telah ditentukan. Tahapan ini dilakukan secara bertahap dan berulang-ulang sesuai dengan jumlah tahapan yang telah dirancang berdasarkan ketebalan plat dan diameter tabung.

f. Tahap finishing untuk memberikan radius kelengkungan yang seragam pada keliling tabung.

\section{d. Perencanaan Mesin Spinning Carpet}

Perencanaan mesin dimulai dengan melakukan analisa gaya dan spesifikasi kerja yang diperlukan agar mesin dapat beroperasi sesuai dengan rancangan yang diinginkan. Berdasarkan hasil analisa gaya dan putaran kerja mesin dapat ditentukan daya yang dibutuhkan untuk menggerakkan mesin tersebut (Sufiyanto, S., 2011).

Prinsip kerja mesin spinning carpet adalah menggunakan torsi untuk memutar tabung spinning dengan putaran yang direncanakan. Air yang terdapat pada karpet basah yang dibilas atau dikeringkan dapat keluar dari lapisan permukaan karpet akibat gaya sentripetal. Dengan hasil perhitungan gaya dan putaran mesin akan diperoleh daya yang dibutuhkan untuk mengoperasikan mesin tersebut.

Adapun perhitungan untuk memperoleh gaya sentripetal benda berputar, persamaan yang dibutuhkan adalah sebagai berikut :

a. Radius girasi $(k)$ bentuk gulungan karpet

$$
k=\sqrt{\frac{I_{z}}{A}}=\sqrt{\frac{\pi \cdot\left(r_{2}^{4}-r_{1}^{4}\right) / 2}{\pi \cdot\left(r_{2}^{2}-r_{1}^{2}\right)}}(\mathrm{mm})
$$

Dimana :

$I_{z}=$ momen inersia penampang $\left(\mathrm{mm}^{4}\right)$

$A=$ luas penampang gulungan karpet $\left(\mathrm{mm}^{2}\right)$

$r_{2}=$ radius luar gulungan karpet $(\mathrm{mm})$

$r_{l}=$ radius luar gulungan karpet $(\mathrm{mm})$

sehingga

$$
k=\sqrt{\frac{\pi \cdot\left(125^{4}-75^{4}\right) / 2}{\pi \cdot\left(125^{2}-75^{2}\right)}}=105(\mathrm{~mm})
$$

b. Kecepatan keliling $(V)$

$$
V=\frac{\pi \cdot d \cdot n}{60000}(\mathrm{~m} / \mathrm{s})
$$

Dimana :

$d$ =diameter gulungan karet yang terkait dengan radius girasi $(k)=2 . k(\mathrm{~mm})$

$n=$ putaran tabung spinning (rpm)

sehingga menghasilkan :

$$
V=\frac{\pi \cdot(2 \cdot 105) \cdot 415,6}{60000}=4,57(\mathrm{~m} / \mathrm{s})
$$

c. Gaya sentripetal $\left(F_{s}\right)$ :

$$
F_{s}=m \cdot \frac{V^{2}}{r}(N)
$$

Dimana

$m=$ massa karpet basah $(\mathrm{kg})$

$r=$ radius putar menggunakan radius girasi $(k)$ sehingga :

$$
F_{S}=1,5 \cdot \frac{4,57^{2}}{0,105}=298(N)
$$

d. Torsi yang dibutuhkan $(T)$

$$
\begin{aligned}
T & =F_{s} . r=298.105=31296 \text { N.mm } \\
& =3129,6 \mathrm{~kg}_{\mathrm{f}} \cdot \mathrm{mm}
\end{aligned}
$$

e. Daya yang dibutuhkan $(P)$

$P=\frac{T \cdot n}{9,74 \cdot 10^{5}}=\frac{3129,6 \cdot 415,6}{9,74 \cdot 10^{5}}=1,33(K W)$

f. Daya yang direncanakan untuk motor penggerak $\left(P_{d}\right)$ 


$$
P_{d}=\frac{P}{\eta_{\text {belt }}}(K W)
$$

Dimana :

$\eta_{\text {belt }}=$ efisiensi transmisi sabuk V

Sehingga :

$$
P_{d}=\frac{1,33}{0,89}=1,5(K W)
$$

Untuk perencanaan poros pada tabung spinning menggunakan rumus-rumus perhitungan sebagai berikut :

a. Tegangan geser ijin bahan poros $\left(\tau_{\mathrm{a}}\right)$

Dimana :

$$
\tau_{a}=\frac{\sigma_{a}}{s f_{1} \cdot s f_{2}}\left(\mathrm{~kg} / \mathrm{mm}^{2}\right)
$$

$\sigma_{a}=$ kekuatan tarik bahan poros $\left(\mathrm{kg} / \mathrm{mm}^{2}\right)$, direncanakan bahan poros ST 37 dengan $\sigma_{a}=$ $37 \mathrm{~kg} / \mathrm{mm}^{2}$

$s_{f l}=$ faktor keamanan (faktor bahan) $=6$.

$s_{f 2}=$ faktor keamanan (faktor bentuk) $=1,3-3$ direncanakan : 3 .

Sehingga :

$$
\tau_{a}=\frac{37}{6.3}=2\left(\mathrm{~kg} / \mathrm{mm}^{2}\right)
$$

b. Diameter poros $\left(d_{s}\right)$

$$
d_{s} \geq\left[\frac{5,1}{\tau_{a}} \cdot K_{t} \cdot C_{b} \cdot T\right]^{1 / 3}(\mathrm{~mm})
$$

dimana :

$K_{t}=$ faktor koreksi (terhadap momen puntir)

- beban halus $K_{t}=2$

- beban kejut $K_{t}=1,0-1,5$ (kecil)

- beban kejut $K_{t}=1,5-3,0$ (besar), direncanakan $K_{t}=3$

$C_{b}=$ faktor koreksi (terhadap momen lentur)

- terjadi lentur $C_{b}=1,2-2,3$ direncanakan $C_{b}$ $=2,3$

- tidak terjadi lentur $C_{b}=1,0$

$T=$ momen puntir (kg.mm)

Sehingga :

$d_{s} \geq\left[\frac{5,1}{2} \cdot 3 \cdot 2,3 \cdot 3129,6\right]^{1 / 3} \geq 37,7 \mathrm{~mm}$

Diameter poros yang digunakan adalah $45 \mathrm{~mm}$.

Sedangkan untuk perencanaan transmisi belt, berdasarkan daya motor penggerak $\left(P_{d}\right)=1,5 \mathrm{kw}$ dan $n_{l}=1400 \mathrm{rpm}$, tipe sabuk V yang memenuhi syarat untuk dipasang pada mesin spinning carpet adalah tipe A dengan ukuran penampang : lebar $(b)=12,5$ $\mathrm{mm}$; tinggi $(h)=9 \mathrm{~mm}$; sudut baji $(\alpha) 40^{\circ}$. Batasan beban yang diterima oleh sabuk $\mathrm{V}$ tipe $\mathrm{A}$ adalah 0,68 $\mathrm{kg}$ (minimum) dan 1,02 kg (maksimum).

\section{e. Manajemen Operasional dan Bisnis}

Operasi adalah suatu aktivitas dalam mentransformasikan input menjadi output yang dapat menambah nilai pada barang atau jasa. Manajemen operasional adalah area bisnis yang berfokus pada proses produksi barang dan jasa, serta memastikan operasi bisnis berlangsung secara efektif dan efisien. Seorang manajer operasi bertanggung jawab mengelola proses pengubahan input yaitu yang dikenal dengan istilah $5 \mathrm{M}+\mathrm{E}$ (dalam bentuk bahan baku (Material), tenaga kerja (Man), modal/uang (Money), mesin/peralatan (Machines), metode (Methods) dan energi (Energy) menjadi output (dalam bentuk barang dan jasa).

Dalam usaha laundry juga perlu adanya manajemen operasional untuk mengkoordinasikan segala bidang/bagian untuk meningkatkan produktivitas usaha yang mempunyai keunggulan bersaing di pasar. Manajemen operasional laundry meliputi :

a) Manajemen pemasaran

Pemasaran adalah suatu proses yang membuat individu atau kelompok mendapatkan apa yang mereka butuhkan dan inginkan dengan menciptakan, menawarkan dan mempertukarkan produk atau jasa yang bernilai kepada pihak lain atau segala kegiatan yang menyangkut penyampaian produk atau jasa mulai dari produsen sampai konsumen. Pemasaran laundry saat ini tidak hanya kemampuan menyampaikan jasa hingga tangan pelanggan tetapi bagaimana jasa tersebut dapat memberikan kepuasan layanan kepada pelanggan (customer satisfaction). Sasaran dari pemasaran adalah menarik pelanggan baru dengan menjanjikan nilai superior pada kualitas layanan laundry, menetapkan harga menarik, mempromosikan secara efektif serta mempertahankan pelanggan yang sudah ada dengan tetap memegang prinsip kepuasan pelanggan. Jika pelanggan laundry sebagian besar adalah mahasiswa yang cenderung berpindah tempat kos/kontrakan, maka strategi promosi harus rutin dilaksanakan baik melalui media cetak (penyebaran brosur, pemasangan spanduk) maupun media sosial melalui Facebook, Instagram atau group BBM/WA, sehingga bagi penghuni kos baru tetap mendapatkan info tentang jasa laundry.

b) Manajemen produksi

Meskipun usaha laundry adalah usaha jasa, proses layanan juga bisa dikategorikan proses 
produksi yang meliputi proses penimbangan dan pencatatan jumlah cucian, proses pencucian, penjemuran/pengeringan, proses setrika dan proses pengepakan. Manajemen produksi pada laundry lebih difokuskan pada usaha mengatur dan mengkoordinasikan penggunaan sumbersumber daya yang ada untuk menghasilkan kualitas layanan yang memuaskan pelanggan. Pemilihan peralatan (mesin cuci, pengering, setrika, meja setrika, keranjang cucian), bahan pencuci, bahan pelembut, bahan pewangi/parfum dan kantung plastik untuk proses packing harus terkoordinasi untuk dapat memberikan layanan yang memuaskan pelanggan. Pelatihan dan pengawasan tenaga kerja harus selalu dioptimalkan karena sangat berpengaruh pada kinerja jasa laundry misalnya selalu mengupayakan untuk tidak adanya kerusakan pakaian, pakaian tertukar atau pakaian hilang, kelunturan, kurang bersih dan lain-lain. Perawatan (maintenance) peralatan perlu dilakukan secara terjadwal, sehingga tidak menggangu proses laundry (menghindari waktu peak season).

c) Manajemen sumber daya manusia

Manajemen sumber daya manusia, disingkat MSDM, adalah suatu ilmu atau cara bagaimana mengatur hubungan dan peranan sumber daya tenaga kerja yang dimiliki secara efektif dan efisien serta dapat digunakan secara maksimal sehingga tercapai tujuan (goal) bersama perusahaan. Pada usaha laundry kinerja sumber daya manusia memiliki peran yang sangat dominan karena sangat mempengaruhi kualitas layanan yang bisa dirasakan oleh pelanggan. Seleksi dan proses recruitment yang ketat disesuaikan dengan tingkat pendidikan (misalnya minimal SMU/SMK), pelatihan proses laundry dari awal (penerimaan cucian) sampai cucian kembali ke pelanggan, evaluasi kinerja di masing-masing bagian, bila diperlukan bisa dilakukan mutasi sesuai dengan tingkat ketelitian tenaga kerja terutama pada proses penghitungan jumlah cucian dan proses setrika (bagian yang memiliki peluang besar terjadi kesalahan). Untuk meningkatkan kinerja karyawan laundry bisa dilakukan dengan memberikan kompensasi sebagai reward.

d) Manajemen keuangan

Manajemen keuangan adalah suatu kegiatan perencanaan, penganggaran, pemeriksaan, pengelolaan, pengendalian, pencarian dan penyimpanan dana yang dimiliki oleh suatu organisasi atau perusahaan. Pada usaha laundry bagian ini meliputi : menetapkan kebijakan harga (tidak selalu yang murah di senangi pelanggan), melakukan pengawasan terhadap pengeluaran untuk operasional dan pemasukan dari pelanggan, melakukan pencatatan untuk uang/barang yang biasanya tertinggal di saku dan memastikan uang atau barang kembali pada pemiliknya dan menghitung nilai keuntungan usaha laundry tiap bulan.

Setiap usaha pasti menghadapi beberapa kendala. Kadang-kadang terjadi pemadaman air PDAM dan Tenaga Listrik PLN yang bisa menyebabkan terhambatnya proses laundry. Untuk itu sebaiknya usaha laundry mempunyai tangki atau tandon air dan genset. Adanya kartu anggota pelanggan yang berisi data nama, alamat dan nomor telepon sangat diperlukan untuk memudahkan menghubungi pelanggan jika sewaktu-waktu terjadi kendala dalam proses laundry.

\section{KESIMPULAN}

Perbaikan teknologi yang telah diberikan pada mitra Bali Laundry dapat memberikan manfaat dalam peningkatan usaha jasa laundry carpet menjadi lebih maksimal. Aplikasi penggunaan mesin spinning carpet ini berdampak pada lama proses pengeringan karpet menjadi lebih cepat 3 kali dibandingkan dengan cara sebelumnya.

Manajemen operasional dan bisnis yang baik dan tepat diperlukan dalam pengembangan bisnis industri kecil agar memiliki daya saing yang lebih besar. Strategi ini diberikan dalam bentuk workshop kepada pelaku usaha jasa laundry carpet disekitar lokasi mitra IbM di daerah Kelurahan Mertojoyo Kecamatan Lowokwaru Kota Malang.

\section{REFERENSI}

Aaron D. Deutsman, Walter J. Michels and Charles E. Wilson, 1975, Machine and Design, Theory and Practice, Maemilan Publishey. Co. Inc. New York.

Aapold, Felier, Reinhard, Schmidt, 1982, Tehnology of The Metal Trade, Deutsche Gesellschaft-fur Technische Zuz sammenarbeit (GTZ) Gmbh, Federal Republic of Germany. 
Afandi, R. R. A., Setiawan, C. B., Siswanto, H. E., 2011, Peningkatan Kualitas Pengerolan Pipa Untuk Pembuatan Frame Lengkung Di Bengkel Teknik Dengan Mesin Roll Mekanik, PKM Teknologi, Jurusan Teknik Mesin, Universitas Merdeka Malang.

Ktari, Ahmed, et. all, 2012, Modeling And Computation of The Three-Roller Bending Process Of Steel Sheets, Journal of Mechanical Science and Technology, DOI: 10.1007/s12206011-0936-4

Niemen G, 1982, Elemen Mesin, edisi ke II, Erlangga, Jakarta.

Prawirosentono, Suyadi, 2001, Manajemen Operasi, Analisis dan Studi Kasus, Edisi-3, Bumi Aksara, Jakarta.

Smith, Bill and Mark King, 2002, Bending Square and Rectangular Tubing, The Tube \& Pipe Journal.

Sufiyanto, S., 2011, Analisis Proses Pengerolan Pipa Dengan Roll Bending, Transmisi, Vol. 7 No. 1, Teknik Mesin Universitas Merdeka Malang

Sularso, 1987, Dasar Perencanaan Mesin dan Pemilihan Elemen Mesin, cetakan ke enam, Pradnya Paramitha, Jakarta.

Takeshi Sato, 1987, Menggambar Mesin, cetakan ke delapan, Pradnya Paramitha, Jakarta.

http://www.thefabricator.com/article/bending/arundown-on-rolling-machines, diakses

September 2016

https://www.scribd.com/doc/76108732/makalah-

SKB, 15 September 2016

http://adaddanuarta.blogspot.co.id/2012/08/contoh -makalah-studi-kelayakan-bisnis.html, 15 September 2016

http://nabilawirija.blogspot.com/2012/12/normal-

0-false-false-false-in-x-none-x.html, $\quad 15$ September 2016

Roger G. Schroeder, 1992, Manajemen Operasi, Pengambilan Keputusan Dalam Fungsi Operasi, Penerbit Erlangga, Jakarta. 